\title{
Factors Influencing Land Degradation in the Billate Water shade: The Case of Dimtu and Shelo Sub Water shade, Southern Ethiopia
}

\author{
Tamrat Guja Asale ${ }^{1} \quad$ Temesgen Zewde Zeleke ${ }^{2}$ \\ 1.College of Business and Economics, Wolaita Sodo University, Wolaita Sodo, Ethiopia \\ 2.College of Agriculture, Wachemo University, Durame, Ethiopia
}

\begin{abstract}
The economic growth of developing countries depends on the performance of the agricultural sector which in turn depends on how the natural resources are managed. Agriculture in Ethiopia is hindered by many factors among which land degradation in the form of soil erosion and nutrient depletion plays major role. Land degradation resulting from soil erosion and nutrient depletion is one of the most challenging environmental problems in Ethiopia. It has economic loss (food, pasture, and fuel wood) at household level. Billate is particular water shade found in the southern Ethiopia which faces similar problems. The study was to analyze factors influencing land degradation by examining the degree of land degradation, by identifying the factors influencing land degradation at plot level and by assessing management techniques applied in the billate water shade in the case of Dimtu and Shelo sub water shades, Southern Ethiopia. Both primary and secondary data were collected. Primary data were collected from 92 sampled households. Binary logit model analysis was used to determine factors affecting land degradation. The results revealed that only $10.9 \%$ of the sample households' plots were undegraded and $89.1 \%$, degraded with different degrees (slightly degraded, moderately degraded and severely degraded). The model results reveal that seven explanatory variables, education, plot ownership, livestock holding, family size, slope, and market distance from the residence were found to be statistically significance in affecting degradation at less than $10 \%$ probability level. The Billate Water shade is one of highly degraded areas with different degrees of land degradation (slightly degraded, moderately degraded and severely degraded). Understanding some of factors that determine land degradation of the area would contribute to devise appropriate strategies to achieve the desired change in SWC measures and to alleviate damages of land degradation in the study area. Sustainable land management systems must be developed to reduce further degradation and restore the productivity of the eroded land. Thus selecting strategies and intervention areas need to be given due attention in the near future.
\end{abstract}

Keywords: Land degradation, Water shade, Land management, Household, Plot size

DOI: $10.7176 / \mathrm{JNSR} / 9-7-04$

Publication date: April $30^{\text {th }} 2019$

\section{INTRODUCTION}

The rain fed agriculture determines the agrarian economy of most developing countries. The economic growth of developing countries depends on the performance of the agricultural sector, and the contribution of this sector depends on how the natural resources are managed. However, in the majority of developing nations, the quality and quantity of natural resources are decreasing resulting in more severe droughts and floods (Fikru, 2009). In most of the developing countries, the major factor for land degradation is the improper and unsustainable land use and management due to population pressure and small farm sizes, land tenure insecurity, land redistribution, limited access to credit and education (IFPRI, 2005). Land degradation is considered as a major global issue due to its adverse impact on agricultural productivity and sustainability which is a key source of the "poverty trap" (Fitsum and Holden, 2006). In Ethiopia, land resources are becoming increasingly scarce, and the quality of resources such as soil; water, plants and animals are decreasing as a result of improper management. Land degradation due to soil erosion and nutrient depletion pose a serious problem on the livelihood of the rural producers in developing world (FAO, 2000). Although land degradation is very serious problem, most of the studies conducted on land degradation in Ethiopia have focused on the identification of the rate of soil erosion and on biophysical aspects of the problem, particularly on soil erosion generally without much emphasis on the economic, social, or institutional factors that affect land degradation at a plot level (Getachew, 2005). Similarly, the policy responses to land degradation in Ethiopia have focused mainly on the technical aspects, particularly on physical structure such as terraces and bunds.

The general objective of the study was to analyze factors influencing land degradation in the Billate water shade in the case of Dimtu and Shelo sub water shades, Southern Ethiopia. Specifically, this study was emphasized to examine the degree of land degradation, to identify the factors influencing land degradation at plot level and to assess management techniques applied to manage land resources during agricultural activities in the study area. 


\section{Methodology}

Billatte water shade is located between two woredas namely Diguna Fango woreda and Boricha woreda which are respectively found in Wolaita Zone and sidama Zone, Southern Ethiopia.

\subsection{Sources and Methods of Data Collection}

Both qualitative and quantitative data were used in this study. Those data were included demographic, socioeconomic, institutional and biophysical features of the area. The data required for this study were collected from both primary and secondary sources. The primary data were generated from randomly selected sample households were interviewed by using a structured questionnaire in the water shade. In addition to this field observation and group discussion were conducted to collect the plot level data, the soil degradation problem (extent and distribution) and potential opportunities of the area and the status of conservation measures within the water shade and the community and biophysical resources. Secondary data were collected from published and unpublished documents of Agriculture and Rural Development Offices.

\subsection{Determination of sample size and Sampling Technique}

For this particular study purposive sampling for selection of water shade followed by random sampling technique were used. Two water shades Dimtu and Shelo were selected purposively because of the severity of land degradation problem. According to the cumulative report of Diguna Fango woreda and Boricha woreda, 2016, the water shades has a total of 2,966 HHs and 1,481 HHs from Dimtu and 1,485 HHs from Shelo sub-water shades. Simple random sampling technique was used to select the sampled households. The sample size was determined by using Cochran (1977) as calculated below.

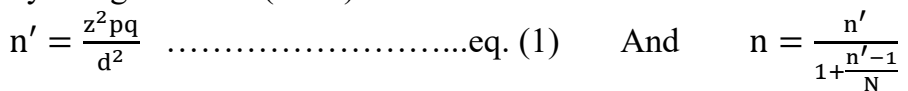

Where, $\mathrm{n}^{\prime}$ and $\mathrm{n}$ are the desired sample sizes when the population is greater than 10,000 and less than 10,000 respectively. $\mathrm{Z}=95 \%$ confidence limit ( $\mathrm{z}$-value at 0.05 is 1.96 ) and $\mathrm{P}=0.05, \mathrm{q}=1-0.05$ i.e. ( 0.95 ), and $\mathrm{d}=$ margin of error or degree of accuracy (0.05). The result from equation 1 is 75 , but equation 2 was used since number of population is less than 10,000 .

$\mathrm{n}=\frac{\mathrm{n}^{\prime}}{1+\frac{\mathrm{n}^{\prime}-1}{\mathrm{~N}}} 75 /(1+(75-1) / 2966)=77$

Donald (1967) recommended taking a random sample of $10-20 \%$ of non-respondents to use in non-respondent follow-up analyses and $20 \%$ of 77 were 15.4 added as contingency. Therefore, Sample size used (n') in this study was $77+15=92 \mathrm{HHs}$.

\subsection{Method of Data analysis}

Both descriptive and econometric analysis (logit regression model with SPSS version 16) was used.

\section{Model specification}

Dependent variable is dummy that takes the value of zero or one depending on whether the given land is degraded or not degraded. According to Gujarati (2004), the dependent variable in logistic model is binary indicating whether land is degraded or not degraded which takes a value of 1 and 0 otherwise respectively.

$$
\mathrm{P}_{\mathrm{i}=}=\frac{1}{1+e^{-z_{i}}}----------------------(1)
$$

Where $\mathrm{Pi}$ is the probability that the ith value being degraded or non-degraded and $\mathrm{Zi}$ is a linear function of $\mathrm{m}$ explanatory variables $(\mathrm{Xi})$, and expressed as:

$$
Z_{i}=\beta_{0}+\sum \beta_{i} x_{i}+u_{i}----------------------------------(2)
$$

Where $\beta 0$ is the intercept and $\beta \mathrm{i}$ are the slope parameters in the model. The slope tells how the Log-odds in favor of being degradation level change as independent variables change. Since the conditional distribution of the outcome variable follows a binomial distribution with a probability given by the conditional mean $\mathrm{Pi}$, interpretation of the coefficient will be understandable if the logistic model can be rewritten in terms of the odds and log of the odds (Gujarati, 2004). The odds to be used can be defined as the ratio of the probability that a farmers plot that degrade $(\mathrm{Pi})$ to the probability that not degrade (1-Pi).

$$
1-\mathrm{P}_{\mathrm{i}}=\frac{1}{1+\mathrm{e}^{\mathrm{z}_{\mathrm{i}}}}---
$$

Then the odds ratio can be written as:

$$
\frac{P_{i}}{1-P_{i}}=\frac{1+e^{z_{i}}}{1+e^{-z_{i}}}=e^{z_{i}}-
$$

Finally, taking the natural logarithm of the odds ratio of equation (5) will result in what is known as the logit model as indicated below: 


$$
\mathrm{Li}=\ln \left[\frac{\mathrm{P}_{\mathrm{i}}}{1-\mathrm{Pi}}\right]=\ln \left[\mathrm{e}^{\beta_{0}}+\sum_{\mathrm{i}=1}^{\mathrm{m}} \beta_{\mathrm{i}} \mathrm{X}_{\mathrm{i}}\right]=\mathrm{Z}_{\mathrm{i}}=\beta_{0}+\sum \beta_{\mathrm{i}} \mathrm{X}_{\mathrm{i}}-----------
$$

If the disturbance term $\mathrm{Ui}$ is taken in to account the logit model becomes:

$$
\mathrm{Z}_{\mathrm{i}}=\beta_{0}+\sum \beta_{\mathrm{i}} \mathrm{X}_{\mathrm{i}}+\mathrm{Ui}
$$

Hence, the above used econometric model was treated against potential variables assumed to affect the degradation status of given plot. To check multicolinearity of the dummy/discrete variables, contingency coefficient (CC) was used and the formula for contingency coefficient is presented as:

$$
\mathrm{CC}=\chi 2 / \mathrm{n}+\chi 2--------------------(7)
$$

Where, $\mathrm{CC}=$ Contingency Coefficient, $\mathrm{n}=$ Sample Size, $\mathrm{X}^{2}=$ Chi-square value. The computed values of contingency coefficient for the dependent dummy/discrete variables were lower which indicates that there is no serious problem of multicolinearity effect among the variables.

\section{Results and Discussion}

\subsection{Land degradation status of the plots}

Based on the field observation assessment results shown in table 1, 10.9\% of the plots of sampled farmers were undegraded and $89.1 \%$ of plots were degraded with (slightly degraded (44.6\%), moderately degraded (35.9\%) and severely degraded (8.7\%)). A similar classification was used by Getachew (2005). The results can serve as an instrument to guide decision as to which status will be given more emphasis to reduce the problem of land degradation.

Table 1: Land degradation status of sample farmers plots;

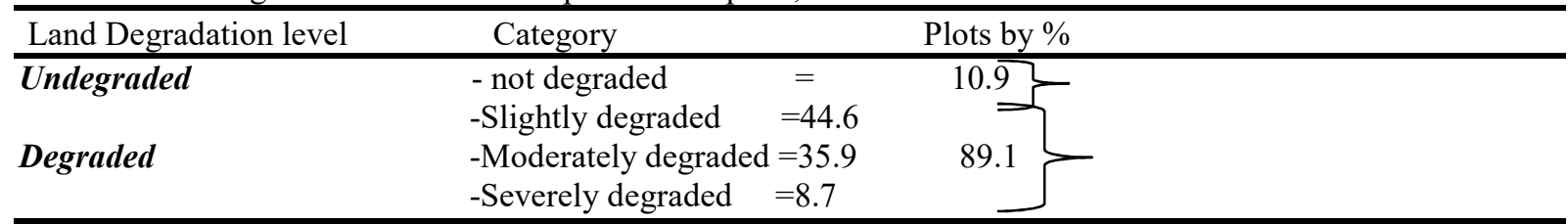

Source: survey result, 2017

Slope is one of the farm attributes that aggravate soil degradation. The results of slopes and status of land degradation are shown in the table 2. The plots of sampled farmers classified as $7.2 \%, 38 \%, 44.6 \%, 5.8 \%$ and $4.4 \%$ of the plots were found to be flat, gentle slope, moderate slope, steep slope and very steep or mountain respectively. The chi-square test indicated that there was systematic relationship between the slopes of the plots and level of land degradation at 1 percent level of significance $(\chi 2=81.901)$. According to Gashaw et al. (2017), high soil erosion rates were recorded in the steeper slope areas of the watershed. Therefore; the finding is consistent with ,Hurni, and Hellden, 1987; Wagayehu and Drake, 2003 cited in Getachew, 2005).

Table 2: Description of slope and status of land degradation of each plot

\begin{tabular}{lccccccc}
\hline \multicolumn{2}{c}{ Slope types } & Undegraded & $\begin{array}{l}\text { Slightly } \\
\text { Degraded }\end{array}$ & $\begin{array}{c}\text { Moderately } \\
\text { degraded }\end{array}$ & $\begin{array}{c}\text { Severely } \\
\text { degraded }\end{array}$ & Total & Chi-square \\
\hline \multicolumn{1}{c}{ The plots } & N.o & N.o & N.o & N.o & N.o & $\%$ & $\chi 2=81.90$ \\
\hline Flat & 29 & 4 & 2 & 1 & 36 & 7.2 \\
Gentle & 40 & 10 & 4 & 3 & 57 & 38.0 \\
Moderate steep & 38 & 19 & 22 & 8 & 87 & 44.6 \\
Steep slope & 11 & 3 & 2 & 5 & 21 & 5.8 \\
Mountain & 4 & 6 & 2 & 7 & 19 & 4.4 \\
Total & 122 & 42 & 32 & 24 & 220 & 100.0 \\
\hline
\end{tabular}

Pearson ch.sq $=81.901 \mathrm{sig}=0.000 * * *$ Likelihood ration $=58.78, \mathrm{~L}-\mathrm{by}-\mathrm{L}$ Association $=32.31$, *** is significant at less than $1 \%$ probability level

Source: Survey result, 2017

\subsection{Soil and water management practices}

In the study areas there are major types of soil management and conservation measures practiced; like Soil bund, fannya juu, cutoff drains, water way, stone bund and area closure are newly introduced SWC technologies. Soil burning, mulching, compost manure, green manuring, crop rotation, grass strips, and others were common culturally/indigenously practiced SWC measures in both water shades. In these areas soil bunds along contours are widely used by farmers on cultivated land. These measures, however, are not enough to control land degradation in the form of soil erosion. In both water shades, based on the slope and the availability of stone, a combination of stone and soil bund, and hillside terrace were constructed. The Agricultural and Rural Development Office of the woredas also promoted a lot of soil conservation technologies through mass mobilization. According 
to the reports of Diguna fango and Boricha Agriculture and Rural Development Office in the past 6 years about 7848.2 ha of soil and stone bunds, 4,749km of fannya juu, 17,715Ha area closure and 758,628 number of micro basins were constructed (Table 3).

Table 3: Soil and water conservation measure done in the past six year;

\begin{tabular}{|c|c|c|c|c|}
\hline \multicolumn{5}{|c|}{ Type of SWC activity } \\
\hline Year (No ) & Fannya juu $(\mathrm{km})$ & Soil \& Stone bund $(\mathrm{Km})$ & Area closure $(\mathrm{Ha})$ & Micro Basin \\
\hline 2011 & 456 & 278.4 & 1814 & 27,072 \\
\hline 2012 & 851 & 549.0 & 3067 & 79,658 \\
\hline 2013 & 643 & 1560.6 & 3142 & 118,294 \\
\hline 2014 & 809 & 1879.4 & 3360 & 146,765 \\
\hline 2015 & 981 & 2017.0 & 3101 & 179,746 \\
\hline 2016 & 1009 & 1563.8 & 3231 & 207,093 \\
\hline Total & 4,749 & $7,848.2$ & 17,715 & 758,628 \\
\hline
\end{tabular}

Source; cumulative secondary data (ARDO, 2017)

The mixed farming systems in the study areas had long traditional experience of using oxen and hand tools for tillage in crop production. Crop plots were cultivated by pair of oxen with ploughing called "maresha" and $75 \%$ of respondents cultivate their land using maresha and 20.6\% cultivate their land using hand tool. During the field observation even some of the farmers by using Maresha plow up and down hill which initiates soil erosion through furrow.

Table 4. Kind cultivation system farmers experience in farm

\begin{tabular}{lll}
\hline Cultivation system & N.o & $\%$ \\
\hline Ploughing using hand tool & 18 & 20.6 \\
Use of maresha & 72 & 75.0 \\
Other cultivation methods & 2 & 2.4 \\
Total & 92 & 100.0 \\
\hline
\end{tabular}

Source; survey result (2017)

\subsection{Determinants of Land Degradation}

As the results of the binary logit regression model showed in the table 5, seven variables were found to be significantly related to the land degradation at the different probability level among fourteen hypothesized explanatory variables in the study area. These are household head education (Educatin), plot owner ship (Plotown), total family size (Famlysiz), slope level of plot (slope), plot distance (plotdist), market distance (mrktdist), livestock holding(TLU). On the other hand, the coefficients of the variables such as sex of the household (Sex), age of the household (Age), social responsibility of the household head (Soclrsposty), the total farm size owned (Farmsiz), the plot number of the household in (Plotnumbr), land use type (Landuse) and institutional support (Institnlsuprt) were not significant implying that they were less important to affect land degradation in the study area. It does not mean that, the variables that not significant, were not affect degradation, it means that, the degree of influence differs or less than for insignificant variables. 
Table 5: Binary logit regression model results.

\begin{tabular}{lllllc}
\hline Variable code & $\begin{array}{l}\text { Estimated } \\
\text { Coefficient (B) }\end{array}$ & $\begin{array}{l}\text { Standard } \\
\text { error (S.E.) }\end{array}$ & $\begin{array}{l}\text { Wald } \\
\text { statistics }\end{array}$ & $\begin{array}{c}\text { Significant } \\
\text { level (Sig.) }\end{array}$ & $\begin{array}{c}\text { Odds ratio } \\
\text { Exp (B) }\end{array}$ \\
\hline Sex & +1.985 & 1.070 & 4.376 & .220 & 8.620 \\
Age & -2.020 & .886 & 5.342 & .111 & 7.578 \\
Soclrespns & -.690 & .891 & .766 & .129 & .458 \\
Educatn & -1.439 & .818 & 3.093 & $.015^{* *}$ & 6.226 \\
Famlsiz & +.609 & .704 & .984 & $.061 *$ & 2.011 \\
Slope & +3.353 & .911 & 13.242 & $.000^{* * *}$ & 48.60 \\
Plotdst & +1.230 & .703 & 3.012 & $.080^{*}$ & 3.50169 \\
Mrktdst & -.831 & .810 & 1.051 & $.035^{* *}$ & .436 \\
Plotnumbr & +1.378 & .924 & 2.226 & .126 & .252 \\
Farmsiz & -.748 & .931 & .645 & .122 & .573 \\
TLU & +.601 & .837 & 1.162 & $.001 * * *$ & 18.466 \\
Landuse & +1.097 & 1.102 & .992 & 319 & 2.997 \\
Instisprt & -3.271 & .910 & 12.360 & .149 & 17.012 \\
Plotownsp & -4.728 & 1.260 & 13.870 & $.000^{* * *}$ & 98.065 \\
Constant & -4.348 & 1.153 & 14.228 & .000 & .011
\end{tabular}

Note; Percentage of correct prediction $(R)=0.760$ Log likelihood $=70.041$ Chi square $=89.051$ Exp $(B)$ : shows the predicted changes in odds for a unit increase in the predictor, Number of observations, $N=92 * * *$ and ***Significant at 0.1, 0.05, and 0.01 level, respectively

Source: survey result, 2017

A positive estimated coefficient in the model implies increase in the severity of land degradation with increased in the value of the explanatory variable. Whereas negative estimated coefficient in the model implies decreasing severity with increase in the value of the explanatory variable.

\section{Conclusions and Recommendations}

\subsection{Conclusions}

The economic growth of developing countries depends on the performance of the agricultural sector, and the sector depends on how the natural resources are managed. However, the quality and quantity of natural resources are decreasing and resulting in more severe droughts and floods (Fikru, 2009). Land degradation is one of the major factors affecting Agricultural development in Ethiopia. Soil erosion and nutrient depletion are the major cause of land degradation in Ethiopia. The rationale of this study was to analyze factors influencing land degradation by examining the degree of land degradation, by identifying the factors influencing land degradation at plot level and by assessing management techniques applied in the Billate water shade in the case of Dimtu and Shelo sub water shades, Southern Ethiopia. The data required for this study were collected from both primary and secondary sources. The primary data were generated from 92 randomly selected sampled households, field observation and group discussion. Secondary data were collected from published and unpublished documents and reports of Agriculture and Rural Development Office. Both descriptive and econometric analysis (logit regression model with SPSS version 16) was used.

The results revealed that only $10.9 \%$ of the sampled households' plots were undegraded and $89.1 \%$ of the sampled households' plots were degraded with different degrees (slightly degraded (44.6\%), moderately degraded $(35.8 \%)$ and severely degraded $(8.7 \%)$ ). Most of the respondents used to apply cultural SWC practices than newly introduced once. The cultivation system and type of crops grown have encouraged the land to soil erosion and nutrient depletion in the study area. Traditionally, crop plots were cultivated by pair of oxen with traditional ploughing "maresha" (local traditional equipment for ploughing). According to field observation even some of the farmers by using Maresha plow up and down hill, initiates soil erosion through furrow. The model results reveal that seven explanatory variables, education, plot ownership, livestock holding, family size, livestock holding, slope, and market distance from the residence market distance had effect on land degradation, were found to be statistically significance in affecting degradation at different significance level. Therefore, Understanding the demographic, socio-economic institutional and biophysical factors that influencing land degradation of the area would contribute to devise appropriate strategies to achieve technical change in land management process and to alleviate damage of land degradation in the study area and other similar areas of the region. In selecting priority intervention areas in the rehabilitation of land degradation, the action plan should consider the socio-economic and specific plot characteristics as well as farmers own preferences. 


\subsection{Recommendation}

The recommendations of the current study will help to develop Sustainable land management systems and to reduce further degradation and restore the productivity of the eroded land.

$>$ The existing crop production and cultivation system must be supported by integrating traditional with newly introduced appropriate land management practices.

$>$ The government should be concerned by selecting priority intervention areas in rehabilitation of degraded land, the socio-economic and specific plot characteristics and participate farmers as well.

\section{References}

Boricha Woreda Agricultural and Rural Development Office, 2016. First quarter report. Unpublished. shelo.

Cochran WG. John Wiley \& Sons:New York(1977). Sampling Techniques. Pp.74-76.

Donald, M. N. (1967). Implications of non-response forThe interpretation of mail 81 questionnaire data. Public Opinion Quarterly, 24(1), 99-114.

Duguna Fango Woreda Agricultural and Rural Development Office, 2016. annual report. Unpublished.

FAO (2000). Rural Poverty, Risk and Development, by M. Fafchampus, FAO economic and social development paper No. 144. Rome

Fikru Assefa (2009). Assessment of adoption behavior of soil and water conservation practices in the Koga watershed, highlands of Ethiopia. A Thesis Presented to the Faculty of the Grad School of Cornell University Master of Professional Studies.

Fitsum Hagos and S. Holden.(2006). Tenure security, resource poverty, risk aversion, public programs and household plot level conservation investment in the highlands of norther Ethiopia: http://www.arts .cornell.edu/econ/75devconf/papers/hagos doc

Gashaw et al. (2017) 6:1 DOI 10.1186/s40068-016-0078-x. Erosion risk assessment for prioritization of conservation measures in Geleda watershed, Blue Nile basin, Ethiopia. Environmental System Research.

Getachew Adugna (2005). Determinants of land degradation in the lake tana basin and its implications for sustainable land management; a thesis submitted to the department of agricultural economics, MSc . Alemaya University

Gujarati, D.N. (2004). Essentials of Econometrics.4th edition.Mc-Graw-Hill Companies. 1003p.

HURNI(1993). Land degradation, famine and land resource scenarios in Ethiopia. pp. 27-61 in D. Pimentel (ed). World soil erosion and conservation. Press Syndicate, University of Cambridge, Cambridge.

IFPRI (International Food Policy Research Institute), WUR (Wageningen University and Research Center) and EEPFE (Environmental Economics Policy Forum of Ethiopia). (2005). Poverty and Land Degradation in Ethiopia: How to Reverse the Spiral?

Wogayew Bekele.,Drake, L (2003). Soil and water conservation decision behavior of subsistence farmers in the eastern highlands of Ethiopia: a case study of the Hunde-Lafto area. 